УДК 37.015 .3

DOI:

Krzysztof, Tadeusz Juszczak, Doktor nauk humanistycznych Wyższa Szkoła Bankowa w Poznaniu

\title{
Zespół wypalenia zawodowego u nauczycieli - wybrane problemy
}

Syndrom wypalenia zawodowego $w$ zawodzie nauczyciela nie jest zjawiskiem nowym. W ostatnich latach pojawito się szereg publikacji, które nie tylko wyjaśniaja to zjawisko, ale wskazują wyraźnie, że występuje ono w populacji polskich nauczycieli. Jest to stan niepokojacy, bowiem syndrom ten ma negatywny wplyw nie tylko na osobę nauczyciela, ale także na osoby, z którymi styka się on w pracy zawodowej.

Pogtębiona analiza problemu wypalenia zawodowego, odkrywanie mechanizmówjego powstawania, pomoże znaleźć skuteczne środki przeciwdziałania temu zjawisku i stanie się istotnym czynnikiem zmiany sytuacji zawodowej każdego pracownika, szczególnie zaś nauczycieli.

Stowa kluczowe: stres; zespót; wypalenie zawodowe; pedagog.

Bibl. 26.

Kshishtof Jushchak, Ph.D.(Humanities), Poznan Higher School of Banking

\section{TEACHER'S BURNOUT SYNDROME: TOPICAL PROBLEM}

The teacher's professional burnout syndrome is not a new phenomenon. This is an alarming state because the syndrome has a negative effect. The in-depth analysis of the problem has been carried out in the article, the search for mechanisms for solving professional burnout, especially for the teaching profession, has been done.

It has been determined that professional burnout syndrome is a widespread practice among employees of the modern school in the Republic of Poland. It is accentuated that in recent years a number of publications have appeared that not only explain this phenomenon, but clearly show that it is happening among Polish teachers. This disturbing situation has a negative impact not only on the teacher, but on the people with whom he or she communicates in the professional activity and in personal life. Therefore, educational institutions and members of the teachers' families should be involved in the process of solving this situation, to prevent its occurrence.

The factors that cause the burnout syndrome of the teacher in the article are as follows: lack of professional recognition (small opportunities for career growth, low wages, lack of recognition for professional success and competence of teachers); overload in professional activity (big responsibility for pupils, small leisure opportunities, work beyond normal, including the need to constantly prepare for classes, lack of individualization of the educational process, misconduct of pupils (low discipline, lack of personal culture, problems associated with support discipline of the pupils); absence of positive microclimate in school (conflicts with colleagues, as well as with the authority of the educational institution, pressure from the parents).

It is emphasized that the syndrome of professional burnout of teachers should be considered in the comprehensive solution of such problems associated with the conditions, mechanisms and consequences of this syndrome.

Keywords: stress; syndrome; professional burnout; pedagogue.

W ¡rowadzenie. Współczesne społeczeństwo, charakteryzujące się niespotykaną w poprzednich okresach akceleracją zmian zachodzących we wszystkich sferach życia, zarówno zbiorowego jak i indywidualnego, wymaga od każdej jednostki nieustannego uczenia się nowych strategii funkcjonowania. Zgromadzona wiedza, kompetencje, umiejętności stają się najważniejszymi komponentami kapitału ludzkiego. Nie może zatem dziwić, że w czasach szybkich transformacji społecznokulturowych ,pracy nauczyciela stawia się wysokie wymagania społeczne, niekiedy znacznie wyższe aniżeli wynika to z przydziału obowiązków i zasad kodeksu pracy" [26, 158$]$.

Jak podano w Raporcie UNESCO pt. Uczyć się, aby być podstawowym zadaniem nauczyciela jest kształtowanie osobowości wychowanka i otwieranie przed nim drogi do rzeczywistego świata, który coraz bardziej przestaje poddawać się wyjaśnieniu, jest skomplikowany. Wymaga to osobistego zaangażowania, co oznacza, że zawód nauczycielski wykonuje się całym sobą: nie mniej ważne niż to, co nauczyciel mówi, jest także i to, jakie ma przekonania, jakimi wartościami kieruje się w życiu zawodowym jak też osobistym. Świadomość konieczności sprostania określonym wymaganiom przyczynia się do wzrostu natężenia czynników powodujących stres, a $w$ rezultacie prowadzi do niezadowolenia $z$ wykonywanej pracy, chronicznego zmęczenia, w skrajnych przypadkach nawet do niepokojącego zjawiska - wypalenia zawodowego.

Jest to stan niepokojący. Syndrom ten ma bowiem 


\section{Zespół wypalenia zawodowego u nauczycieli- wybrane problemy}

negatywny wpływ nie tylko na osobę nauczyciela, ale także na osoby, z którymi styka się on w pracy zawodowej, jak też może przenosić się na życie prywatne i zaburzać relacje społeczne poza kontekstem zawodowym [1, 74], a w konsekwencji prowadzić do spadku jakości życia osoby wypalonej i społeczności, z którymi jest bezpośrednio związana.

Międzynarodowa Organizacja Pracy szacuje, że wypalenie zawodowe lub depresja związane $\mathrm{z}$ wykonywaną pracą zawodową dotyczą co najmniej 10 proc. Amerykanów i Europejczyków. W odniesieniu do grupy zawodowej nauczycieli, europejskie dane statystyczne wskazują, że $60-70$ proc. $\mathrm{z}$ nich przeżywa silny stres wywołany pracą zawodową, a u około $30 \%$ występują oznaki wypalenia.

Z uwagi na troskę o los przyszłych pokoleń, prowadzenie pogłębionej refleksji i dalszych badań w celu redefiniowania problemu zawodowego wypalenia, szukanie skutecznych sposobów niwelowania jego patogennych dla życia indywidualnego i społecznego skutków wydaje się być zamierzeniem niezwykle potrzebnym.

Geneza i definicja. Zanim problematyka wypalenia stała się przedmiotem refleksji naukowej $\mathrm{i}$ badań empirycznych była obecna w literaturze pięknej. Jako jedne z pierwszych wspomina się opowiadanie z 1961 roku pt. „A Burn-Out Case” („Przypadek wypalenia zawodowego”). Autor Graham Green przedstawia w nim historię zmęczonego pracą, światowej sławy architekta, który doświadczając charakterystycznych dla zespołu wypalenia zawodowego symptomów, decyduje się na całkowitą zmianę dotychczasowego trybu życia. Porzuca pracę i zamieszkuje w afrykańskim buszu [13].

Innąilustracją przypadkuwypalenia, najwcześniejszego i chyba najlepiej udokumentowanego w literaturze, jest historia pielęgniarki oddziału psychiatrycznego przedstawiona w artykule Schwartz i Will w 1953 roku - Pani Jones. Jones na skutek przeciążających wydarzeń w pracy i działania różnorodnych stresorów zaczęła odczuwać zmęczenie, bezsilność fizyczną i psychiczną, niechęć wobec pacjentów oraz brak satysfakcji z wykonywanych zadań [14]. Obserwacja jej zmagań nie pozostawia żadnych wątpliwości, że uruchomiony został proces wypalenia.

Przytoczone przypadki upoważniają do stwierdzenia, że zjawisko wypalenia było obecne w świadomości społecznej znacznie wcześniej niż pojawiły się systematyczne badania i opracowania naukowe dotyczące tego zagadnienia.

Do języka nauki termin „wypalenie” został wprowadzony we wczesnych latach siedemdziesiątych XX wieku - równolegle i niezależnie od siebie - przez psychiatrę H. Freudenbergera i psychologa społecznego Ch. Maslach.

Freudenberger fenomen wypalenia zdefiniował jako stan zmęczenia czy frustracji wynikający z braku równowagi pomiędzy energią wkładaną w realizację jakiejś sprawy, a nagrodami uzyskanymi za poniesiony wysiłek. Stan ten, przejawiający się na poziomie fizycznym (chroniczne zmęczenie, brak energii, osłabienie, zaburzenia snu, zwiększona podatność na zachorowania), behawioralnym (skłonność do reagowania złością, duża zmienność zachowania) oraz psychologicznym (przygnębienie, uczucie znudzenia, zniechęcenia, rozdrażnienia i złości, labilność emocjonalna) [17,9], krystalizuje się powoli, przez dłuższy okres przeżywania stresu i angażowania całej energii życiowej i w końcowym efekcie wywiera negatywny wpływ na motywację, przekonania $i$ zachowanie [6, 167].

Maslach przyjęla, że wypalenie jest „psychologicznym zespołem wyczerpania emocjonalnego, depersonalizacji oraz obniżonego poczucia dokonań osobistych, który może wystąpić u osób, które pracują z innymi ludźmi w pewien określony sposób" [9, 135]. Wyczerpanie emocjonalne odnosi się do poczucia danej osoby, że jest nadmiernie wyeksploatowana emocjonalnie, a jej zasoby emocji zostały na skutek kontaktów z innymi ludźmi znacznie uszczuplone. Charakterystyczne dla wyczerpania jest poczucie nadmiernego przeciążenia, zniechęcenia do pracy oraz obniżonej aktywności. Towarzyszy temu utrata energii, zapału do działania, brak radości życia, zwiększona impulsywność i drażliwość. Depersonalizacja dotyczy zaburzonych stosunków interpersonalnych, co przejawia się w skłonności do traktowania ludzi, z którymi się pracuje w sposób obojętny, przedmiotowy, pogardliwy, a nawet bezduszny. Istnieje realne niebezpieczeństwo, że postawa obojętnego reagowania na innych ludzi i ich problemy zostanie utrwalona i prowadzić będzie do dehumanizacji. Natomiast obniżona ocena własnych dokonań jest tendencją do negatywnego oceniania własnej pracy i kompetencji zawodowych. Brakowi satysfakcji związanej z pracą zawodową, mającej swe źródło w rzeczywistym pogorszeniu jakości pracy, towarzyszą nastroje depresyjne, samokrytyka, przekonanie o własnej nieprzydatności i bezwartościowości. Wzrasta poczucie nieadekwatności zawodowej i w rezultacie może pojawić się poczucie bezsensu wykonywanej pracy $[8,13-31]$.

Według A.M. Pines i E. Aronsona ,wypalenie jest stanem fizycznego, emocjonalnego i psychicznego wyczerpania powodowanego przez długotrwałe zaangażowanie w sytuacje, które są obciążające pod względem emocjonalnym" [10,35]. Fizyczne wyczerpanie łączy się ze spadkiem energii, poczuciem 
ciągłego zmęczenia i słabości. Odczuciom tym towarzyszą różnorodne fizyczne i psychosomatyczne dolegliwości. Wyczerpanie emocjonalne przejawia się bezradnością, poczuciem beznadziejności, osaczenia. Natomiast wyczerpanie psychiczne wyraża się w negatywnych postawach wobec siebie, pracy i własnego życia.

Z kolei J. Edelwich i A. Brodsky uważają, że wypalenie jest rezultatem stopniowego narastania rozczarowania pracą zawodową. W procesie tym wyróżniają cztery fazy: entuzjazmu, stagnacji, frustracji i apatii [22, 49 - 52]. Entuzjazm cechuje pracowników w początkowym okresie kariery zawodowej i wyraża się idealizmem i istnieniem licznych planów związanych z pracą zawodową. Towarzyszą temu mało realistyczne oczekiwania i nadzieje. Stagnacja charakteryzuje się wyciszeniem i wzrostem krytycyzmu, które są efektem zarówno zdobytych doświadczeń zawodowych, jak i doznanych rozczarowań. Zauważalne jest zainteresowanie komfortem w pracy i dbałość o własną wygodę. Frustracja jest efektem doznanych rozczarowań zawodowych i następstwem niezaspokojenia potrzeb i pragnień, które jednostka wiązała $z$ pracą. W tej fazie boleśnie przeżywana jest przez pracownika obecność różnorodnych zewnętrznych czynników prowadzących do wypalenia, szczególnie takich, jak: niska płaca, brak dostatecznego wsparcia i pomocy ze strony instytucji, brak właściwej organizacji pracy, niedostatki w zarządzaniu i kierowaniu placówką, niedostateczne wyposażenie w sprzęt. Apatia jest pochodną doznanych rozczarowań i frustracji. W tej fazie narastają u pracownika tendencje izolacyjne, prowadzące do wycofywania $z$ aktywności zawodowej zarówno w sensie fizycznym, jak i psychicznym. Fizyczne wycofanie przybiera formy unikania czy ograniczania do minimum kontaktów z klientem, następuje przesunięcie punktu ciężkości z udzielania pomocy na doglądanie, pojawia się niechęć do wchodzenia $w$ bezpośrednie relacje ze współpracownikami oraz opór przed chodzeniem do pracy. W płaszczyźnie psychicznej wzrasta obojętność wobec klientów i ich problemów, pojawia się skłonność do zrzucania winy na nich lub otoczenie, zauważalna staje się utrata pozytywnych uczuć do podopiecznych, kontakty zawodowe stają się powierzchowne. Edelwich i Brodsky podkreślają, że taka sytuacja wymaga ingerencji z zewnątrz $\mathrm{w}$ formie profesjonalnej pomocy psychologicznej. W związku z tym widzą potrzebę wyodrębnienia piątej fazy, zwanej fazą interwencji. Zaznaczają jednocześnie, że pomoc jest tym trudniejsza, im bardziej zaawansowany jest rozwój wypalenia.

Inaczej proces wypalenia ujmują R. Golembiewski i jego współpracownicy. Uznają oni, że wypalenie jest następstwem pracy w przeciążających dla jednostki warunkach i prowadzi do spadku jej ogólnej kondycji. Zaznacza się obecnością różnorodnych symptomów zaburzeń (przy czym występują zarówno symptomy fizjologiczne, jak i psychiczne) oraz pogorszeniem jakości wydajności zawodowej (dostrzeganym przez pracownika, jak i jego otoczenie). Przy czym, co w szczególny sposób podkreślają, niesie ono ze sobą poważne następstwa nie tylko dla pracownika, ale również dla instytucji [22, 46 - 47].

Polska badaczka H. Sęk twierdzi, że wypalenie jest wynikiem działania przewlekłego stresu i współdziałania dodatkowych czynników podmiotowych (oczekiwania zawodowe, cele zawodowe, rozbieżności między oczekiwaniami a realiami życia, poziom idealizmu/racjonalizmu, nieświadome motywacje zawodowe, mity, zasoby i kompetencje profesjonalne) i środowiskowych (wymagania w środowisku pracy, warunki wykonywania zawodu, klimat emocjonalno-społeczny w miejscu pracy). „Ogniwem bezpośrednim jest nieskuteczność radzenia sobie ze stresem" [18, 329]. Przy czym, jednostki, które są pewne siebie i przekonane, że kontrolują następstwa swoich działań, są bardziej narażone na syndrom wypalenia niż te, które uważają, że nie mają wpływu na to co dzieje się w ich życiu [3, 3 - 7].

Oryginalny pogląd na zjawisko wypalenia prezentuje A. Bańka. Uważa on, że wypalenie jest stanem stresu przybierającego dwa oblicza: stresu społeczno-kulturowego przeżywanego jako ogólny zanik motywacji, sensu życia, braku perspektyw na przyszłość oraz stresu zawodowego ściśle związanego z konkretnymi warunkami pracy, stałym zmaganiem się z odpowiedzialnością lub zagrożeniem. Do stresu społeczno-kulturowego dochodzi wtedy, gdy nie spełniają się ukształtowane w danej kulturze oczekiwania dotyczące kosztów, jaki każdy powinien ponosić w pracy oraz zysków, które w związku z tym każdemu się należą. To rozróżnienie prowadzi do wyodrębnienia dwóch form wypalenia-zawodowego i egzystencjalnego. Mogą się one w pracy zawodowej wzajemnie warunkować [2, 283 - 320].

Z uwagi na to, że wypalenie obejmuje konfiguracje symptomów, style życia, sposoby myślenia, sytuację zawodową, a konfiguracje te są różne dla różnych osób [4, 59 - 66] nie jest łatwo w jednoznaczny i zadowalający wszystkich sposób je zdefiniować. Niewątpliwie, jest to zjawisko destrukcyjne, reakcja organizmu na stres, stan wyczerpania fizycznego i duchowego, uczucie bezradności, zmęczenie, spadek motywacji do kontynuowania pracy $\mathrm{z}$ dotychczasowym zaangażowaniem, którego przejawy i konsekwencje widoczne są nie tylko w środowisku zawodowym, ale też w środowisku rodzinnym. Początkowym jego przejawem jest często cyniczna 


\section{Zespół wypalenia zawodowego u nauczycieli- wybrane problemy}

postawa wobec pracy, a w konsekwencji brak efektywności i doświadczenie porażki.

Czynniki wypalenia zawodowego u nauczycieli. Próby realizacji doniosłych celów pracy przez nauczyciela, jak też silnie odczuwane w tym zakresie społeczne oczekiwania, napotykają często na wiele różnych barier. Wiąże się to $\mathrm{z}$ wieloma czynnikami prowadzącymi do przeciążenia i wyczerpania sił, które przyczyniają się do wzrostu negatywnych postaw wobec siebie, pracy i własnego życia.

Według G. BoyleL'a czynnikami powodującymi pojawienie się wypalenia nauczycielskiego są [15, 48 -49]:

- brak zawodowego uznania - małe możliwości zrobienia kariery zawodowej, niskie uposażenie, brak uznania dla wiedzy i kompetencji nauczycieli;

- przeciążenie pracą - duża odpowiedzialność za uczniów, małe możliwości odpoczynku, nadmiar pracy obejmującej konieczność stałego przygotowywania się do zajęć;

- presja czasu - brak możliwości indywidualizacji procesu edukacyjnego;

- niewłaściwe zachowanie podopiecznych - małe zdyscyplinowanie, braki w zakresie kultury osobistej, problemy związane z utrzymaniem karności uczniów;

- niedostateczne relacje interpersonalne w szkole - konflikty z kolegami, ale także z władzami, naciski ze strony rodziców.

J. Wojciechowska do przyczyn wypalenia zawodowego tkwiących w strukturze profesji zalicza [24]: charakter pracy oraz stopień psychicznego zaangażowania niezbędnego do jej wykonania, powodujący napięcia i stres; presja dużej odpowiedzialności przy braku swobody w zakresie realizacji zadań; wysoki poziom wymagań, angażujący maksymalnie kwalifikacje nauczyciela, prowadzący do zmniejszenia sprawności w rozwiązywaniu trudnych problemów; duże tempo pracy powodujące osłabienie; błędnie dobrany styl zarządzania instytucją tłumiący samodzielność i skoncentrowany na kontroli; niewłaściwe relacje interpersonalne w pracy, wynikające głównie ze stylu zarządzania placówką; niskie wynagrodzenie, będące przyczyną podejmowania dodatkowej pracy.

Badania przeprowadzone przez Ch. J. TraversL'a i C. L. CooperL'a na grupie 1790 brytyjskich nauczycieli, reprezentujących różne typy szkół wykazały, że mają one znacznie szerszy zakres. Stwierdzono m. in., że głównymi przyczynami niezadowolenia $\mathrm{z}$ pracy były czynniki wynikające $\mathrm{z}$ hierarchiczności instytucji szkoły, brak wsparcia dla nauczycieli ze strony dyrekcji, ale również poczucie niezrozumienia dyrektorów przez podwładnych, niekorzystne warunki pracy i częste zmiany dotyczące profesji nauczycielskiej, niepewność socjalna, dwuznaczność roli zawodowej, niski status zawodu i małe możliwości awansu [21].

B. Śliwerski do czynników mających najbardziej negatywny wpływ na samopoczucie zawodowe nauczycieli i odczuwanie przez nich symptomów wypalenia zalicza: błędy w zarządzaniu oświatą, w tym złe warunki pracy, niskie zarobki, które nie zapewniają godnych warunków życia oraz konieczność pracy z coraz większą grupą uczniów nieprzystosowanych społecznie czy sprawiających trudności dydaktyczne lub wychowawcze. Na to wszystko nakładają się trudności życia osobistego, psychiczne zmęczenie pracą, poczucie bezskuteczności działań wychowawczych [20, 14 - 15].

Do wykazu tego H. Przybyła dodaje takie elementy jak: nieodpowiedni styl zarządzania szkołą, zaburzone relacje interpersonalne, zbyt duży wysiłek psychiczny i fizyczny potrzebny w zawodzie nauczycielskim [11,34].

Zdaniem Rudolfa Kretschmana [5]: Stres w zawodzie nauczyciela. Gdańskie Wydawnictwo Psychologiczne. Gdańsk.] do obciążeń w zawodzie nauczycielskim należą: deprecjonowanie przez społeczeństwo pracy nauczyciela (powszechnie uważa się, że jest to zawód niemęczący, z długimi wakacjami, nieszkodliwy dla zdrowia); czas pracy (specyfiką zawodu jest angażowanie się w sprawy mocno naruszające formalne godziny pracy), odczuwanie stresu (obciążenie podwójną presją obowiązki narzucone przez władze oświatowe oraz przez uczniów); ryzyko chorób (zawód nauczyciela plasuje się na drugim miejscu pod kątem chorób układu krążenia oraz serca); kolizja czasu wolnego od pracy z pracą (nauczyciele często realizują zajęcia dodatkowe, które przekraczają wymiar standardowego czasu pracy), pozostałe czynności i obowiązki niepodlegające ścisłemu harmonogramowi szkolnemu (przygotowanie się do zajęć kosztem rezygnacji z wolnego czasu), relacja: chęci a nadmiar obowiązków; wiek.

A. Senejko zauważając, że w literaturze przedmiotu uwagę zwraca się przede wszystkim na czynniki wewnątrzorganizacyjne, środowiskowe i społeczne wypalenia, zainteresowanie swe skupia na czynnikach podmiotowych, które grupuje w kilka kategorii [16, 347 - 351]:

- stres i zaburzenia emocjonalne;

- sztywność postaw, przejawiająca się w ignorowaniu nowych informacji związanych z realizacją ról i zadań zawodowych, nieposzukiwaniem nowych możliwości rozwoju, w tym niechęcią do dokształcania;

- ograniczona zdolność do nabywania wiedzy, która może być połączona z niskim poziomem rozwoju 


\section{Zespół wypalenia zawodowego u nauczycieli- wybrane problemy}

umysłowego, negatywną postawą do dokształcania się;

- ograniczona energia fizyczna, która wiąże się z przeforsowaniem fizycznym zarówno w pracy, jak i poza nią;

- spadek poziomu motywacji do pracy, do awansowania;

- podeszły wiek, a ściślej mówiąc utrwalone przez lata tendencje w zachowaniu jednostki uniemożliwiające jej myślenie dialektyczne i transcendentalne;

- złe nawyki pracy, czyli odkładanie najważniejszych spraw do załatwienia na koniec pracy, pośpiech w realizacji zadań zawodowych, nieprzekazywanie obowiązków zawodowych na innych pracowników.

Uogólniając, źródła wypalenia nauczycieli lokują się w trzech płaszczyznach [25, 119 - 131]: indywidualnej, odnoszącej się do osobowości nauczyciela (np. niska samoocena, defensywność, bierny stosunek do świata, perfekcjonizm, nieracjonalne przekonania o roli zawodowej, unikanie sytuacji trudnych, niskie poczucie sprawności zaradczej); interpersonalnej, dotyczącej wzajemnych relacji nauczyciel - dyrektor, nauczyciel - nauczyciel lub nauczyciel - uczeń (np. rywalizacja, konflikty, brak wzajemnego zaufania, obniżanie poczucia wartości przez jedną ze stron, podważanie kompetencji, blokowanie aktywności twórczej); organizacyjnej, wiążącej się z organizacją miejsca pracy (np. stresory związane ze środowiskiem fizycznym, niemożność pogodzenia obowiązków zawodowych z obowiązkami wobec rodziny lub rozwojem pozazawodowych zainteresowań, styl kierowania niedopasowany do potrzeb pracowników).

Niejednokrotnie dochodzić może do nakładania się na siebie różnych czynników w tym samym czasie. Taka kumulacja może prowadzić do sytuacji ekstremalnie trudnych, w których przezwyciężenie wypalenia bez odpowiedniego wsparcia nie będzie łatwe, a nawet wręcz niemożliwe. Nie wydaje się, by najbliższa przyszłość przyniosła jakieś zmiany i znaczące ułatwienia w pełnieniu roli zawodowej przez pedagogów. Wręcz przeciwnie, przypuszczać należy, że staną przed nimi, jeszcze większe niż istniejące, wyzwania.

Skutki wypalenia zawodowego nauczycieli. Wypalenie zawodowe to niekorzystny stan upośledzający nie tylko zawodowe funkcjonowanie nauczyciela, ale także funkcjonowanie $\mathrm{w}$ innych sytuacjach życiowych. Ofiarami tego zjawiska są najczęściej nauczyciele, którzy identyfikują się emocjonalnie ze swoją pracą, mają nadzieję odnalezienia w niej sensu życia. Zetknięcie z realiami, poczucie niemożności realizacji celów i niewielkiego wpływu na skutek działania przyczyniają się do powolnej, choć skutecznej dekonstrukcji ich osobowości. I choć wypalenie nie jest samo w sobie formą psychopatologii, może prowadzić do szeregu zaburzeń psychicznych, takich jak: uzależnienia, zaburzenia lękowe i depresyjne, a nawet zachowania suicydalne. Zachowania te wywierają istotny wpływ na jakość i wydajność pracy przejawiającą się m. in. mniejszym zaangażowaniem, obniżoną skutecznością, wzrastającą liczbą negatywnych przeniesień w kontaktach z innymi. Co istotne, doświadczająca wypalenia jednostka najczęściej nie dostrzega związku między własnym stanem, a niskimi osiągnięciami i małą aktywnością zawodową.

Analiza statystyczna wielu badań wyraźnie wskazuje, że zawodu nauczyciela w szczególności dotyczy wysokie ryzyko wystąpienia depresji. Jest to szczególnie istotny wynik, ponieważ w kontekście pracy zawodowej depresja przekłada się na takie konsekwencje, jak wysoka absencja oraz trudności w procesie podejmowania decyzji. Po drugie, stwierdzono wyraźne związki obciążeń o charakterze psychospołecznym ze stanem zdrowia nauczycieli. U prawie $30 \%$ badanych stwierdzono symptomy znaczących problemów w obszarze zdrowia psychicznego. Co więcej, były one ściśle skorelowane z obciążeniami psychospołecznymi środowiska pracy. Wyniki te nabierają szczególnej wymowy, gdy powiążemy je z obserwowaną od kilkunastu lat tendencją do szybkiej rezygnacji z aktywności zawodowej przez przedstawicieli profesji nauczycielskiej [12, 308 - 309].

H. Sęk podkreśla, że w zachowaniach nauczycieli z nasilonym zespołem wypalenia zawodowego charakterystyczne są tendencje do skracania bezpośrednich kontaktów z uczniami, niechęć do zajęć pozalekcyjnych, tendencja do nadzorowania uczniów, niechęć do kontaktów z rodzicami i formalizowanie wywiadówek. Zachowania te, budząc sprzeciw rodziców i dyrekcji placówek oświatowych, prowokują do krytycznych uwag, co zwrotnie przyczynia się do wzrostu stresu u nauczycieli oraz szkodzi głównym podmiotom procesu edukacyjnego - uczniom, a następnie wszystkim ogniwom oświaty [18, 325 - 343]. Ponadto, rzadziej wchodzą oni w bliskie podmiotowe relacje z uczniami, przekazują mniejszy zasób wiedzy, udzielają znacznie mniej pochwał i rzadziej akceptują wysuwane przez uczniów pomysły [22, 106].

Konsekwencje wypalenia są więc ponoszone nie tylko przez nauczycieli, ale także niekorzystnie oddziałują na jednostki pozostające w kontaktach $\mathrm{z}$ tymi nauczycielami. Niesie to poważne ryzyko kształtowania osobowości podopiecznych na bazie 
negatywnego wzorca nauczyciela. Nauczyciel, który powinien być człowiekiem nakreślającym wychowankom „perspektywę" staje się pod wpływem „wypalenia” człowiekiem, który w pewnym sensie zaprzecza swej roli. Zniechęcenie, a zarazem brak chęci zmiany czegokolwiek, zmęczenie (również sobą) stają się źródłem wielu niepokojących zmian osobowościowych, które wpływają na samoocenę oraz na kreowanie własnego wizerunku. Nauczyciel taki staje się niejako przyczyną toksycznych zachowań wychowawczych [7, 62].

Negatywne skutki wypalenia zawodowego niestety nie odnoszą się tylko do wykonywanej pracy, ale rozszerzają również na inne sfery życia. Funkcjonowanie wypalonego nauczyciela prowadzi do trudności w pełnieniu ról pozazawodowych, co odbija się niekorzystnie na życiu rodzinnym, wychowaniu dzieci oraz prowadzi do narastania zjawisk patologii społecznych. Nie pozostaje też bez wpływu na strukturę demograficzną społeczeństwa, przyczyniając się do wzrostu liczby jednoosobowych gospodarstw domowych, opóźniania zakładania rodziny, zmniejszania liczby urodzeń, rosnącej liczby rozwodów i rodzin niepełnych.

Podsumowując, wypalenie zawodowe jest problemem indywidualnym i społecznym. ,W kontekście indywidualnym wiąże się z cierpieniem osób, które dotknęło wypalenie zawodowe, z ich emocjonalnym wyczerpaniem i poczuciem niepowodzenia zawodowego. Stwierdzono, że systemy edukacji trącą często bardzo dobrych nauczycieli, zwłaszcza wtedy, kiedy napotykają oni na duże przeszkody administracyjne i związane $\mathrm{z}$ wadliwym zarządzaniem szkołą. Kontekst społeczny ma natomiast nierozerwalny związek z jakością pracy zawodowej, której bezpośrednim, zaangażowanym odbiorcą jest drugi człowiek, często słabszy, zależny i oczekujący pomocy oraz wsparcia, aby rozwijać się, uczyć, zdrowieć” [19, 24].

Zakończenie. Syndrom wypalenia zawodowego jest coraz bardziej powszechnym doświadczeniem wśród pracowników współczesnej szkoły. W ostatnich latach pojawiło się szereg publikacji, które nie tylko wyjaśniają to zjawisko, ale wskazują wyraźnie, że występuje ono w populacji polskich nauczycieli. Jest to stan niepokojący, bowiem syndrom ten ma negatywny wpływ nie tylko na osobę nauczyciela, ale także na osoby, z którymi styka się on w pracy zawodowej i życiu osobistym. „Konsekwencje zjawiska są więc ponoszone i przez pracownika, i przez organizację, obie strony powinny więc mieć swój udział w zapobieganiu jego wystąpienia, szczególnie że za rozwój zjawiska odpowiadają i czynniki jednostkowe, i organizacyjne" $[23,105]$.
W związku z wciąż pojawiającymi się nowymi kwestiami, dotyczącymi wypalenia zawodowego nauczycieli, tematyka związana z uwarunkowaniami, mechanizmami i konsekwencjami tego syndromu jest wciąż niedostatecznie zweryfikowana, wobec tego musi być nadal traktowana jako temat otwarty.

\section{BIBLIOGRAFIA}

1. Anczewska M., Świtaj P., Roszczyńska J., Wypalenie zawodowe, „Postępy Psychiatrii i Neurologii”, 2005.

2. Bańka A. Psychologia pracy, (w:) Strelau J. (red.), Psychologia. Podręcznik akademicki Gdańsk 2000.

3. Bilska E. Jak feniks z popiołu: czyli syndrom wypalenia zawodowego, „Niebieska linia”, 2/2004

4. Burish M. W poszukiwaniu teorii - przemyślenia na temat natury i etiologii wypalenia (Sęk H. (red.), Wypalenie zawodowe. Przyczyny, mechanizmy, zapobieganie, Warszawa 2000.

5. Kretschmann R., Stres w zawodzie nauczyciela, Gdańsk 2003.

6. Litzke S. M., Schuh H. Stres, mobbing i wypalenie zawodowe, Gdańsk 2007.

7. Mastalski J. Szkolne interakcje zaburzające skuteczne wychowanie, Kraków 2005.

8. Maslach C. Wypalenie - w perspektywie wielowymiarowej, (w:) Sęk H. (red.), Wypalenie zawodowe. Przyczyny, mechanizmy, zapobieganie, Warszawa 2000.

9. Pasikowski T., Polska adaptacja kwestionariusza Maslach Burnout Inwentory, (w:) Sęk H. (red.), Wypalenie zawodowe. Przyczyny, mechanizmy, zapobieganie, Warszawa 2000.

10. Pines A. Wypalenie - w perspektywie egzystencjalnej, (w:) Sęk H. (red.), Wypalenie zawodowe. Przyczynyi zapobieganie, Warszawa 2010.

11. Przybyła H. Psychologiczne koszty zespołu wypalenia zawodowego wśród nauczycieli a kierunki pomocy psychologicznej, (w:) Rongińska T., Gaida W., Schaarschmidt U. (red.), Zdrowie psychiczne w zawodzie nauczycielskim, Zielona Góra - Potsdam 1998.

12. Pyżalski J. Obciążenia psychospołeczne w miejscu pracy pedagoga związane z niewłaściwymi zachowaniami uczniów, „Medycyna Pracy”, 4/2008.

13. Schwartz M. Will G., Low morale and mutual withdrawal on a mental hospital ward, „Psychiatry” 16/1953.

14. Schaufeli W., Enzamann D., The burnout compagnion to study and practice: A Critical Analysis, Taylor \& Francis, London 1998.

15. Sekułowicz M. Nauczyciele szkolnictwa specjalnego wobec zagrożenia wypaleniem zawodowym. Analiza przypadków, Wrocław 2005.

16. Senejko A. Podmiotowe czynniki wypalenia zawodowego, (w:) Witkowski S. A. (red.), Psychologiczne wyznaczniki sukcesu w zarządzaniu, Wrocław 2003.

17. Sęk H. Szkoła a wypalenie zawodowe, Poznań 1996.

18. Sęk H. Wypalenie zawodowe u nauczycieli, (w:) Brzeziński J., Witkowski L. (red.), Edukacja wobec zmiany społecznej, Poznań - Torun 1994.

19. Szonert Rzepecka D. Wypalenie zawodowe, (w:) Skłodowski H. (red.), Człowiek w kryzysie psychospołeczne aspekty kryzysu, Łódź 2010. 
20. Śliwerski B. Wypalenie zawodowe nauczycieli, (w:) Kropiwnicki J. (red.), Szkoła a wypalenie zawodowe, Jelenia Góra 1999.

21. Travers Ch. J, Cooper C. L. Mental health, job satisfaction and occupational stress among UK teachers, Work Stress, 1993.

22. Tucholska S. Wypalenie zawodowe u nauczycieli. Psychologiczna analiza zjawiska i jego osobowościowych uwarunkowań, Lublin 2009.

23. Wachowiak J. Dysfunkcyjne zachowania pracowników, Warszawa 2011.

24. Wojciechowska J. Syndrom wypalenia zawodowego, „Nowiny Psychologiczne”, 5-6/1990.

25. Woźniak-Krakowian A. Syndrom wypalenia zawodowego nauczycieli, „Pedagogika”, 22/2013.

26. Zając D. Etyka zawodowa nauczycieli. Wybrane zagadnienia, Bydgoszcz 2011.

\section{REFERENCES}

1. Anczewska, M., Świtaj, P., Roszczyńska, J. (2005). Wypalenie zawodowe, Postepy Psychiatrii i Neurologii [Advances in Psychiatry and Neurology]. [in Polish].

2. Bańka, A., Strelau, J. (red.), (2000). Psychologia pracy [Psychology of work]. Psychologia. Podręcznik akademicki Gdańsk. [in Polish].

3. Bilska, E. (2004). Jak feniks z popiołu: czyli syndrom wypalenia zawodowego [Like a phoenix from ash: a burnout syndrome]. „Niebieska linia”, 2. [in Polish].

4. Burish, M. (2000). W poszukiwaniu teorii przemyślenia na temat natury i etiologii wypalenia [In search of theory - thoughts on the nature and etiology of burnout]. Sęk H. (red.), Wypalenie zawodowe. Przyczyny, mechanizmy, zapobieganie, Warszawa. [in Polish].

5. Kretschmann, R. (2003). Stres $w$ zawodzie nauczyciela [Stress in the teaching profession]. Gdańsk. [in Polish].

6. Litzke, S. M., Schuh, H. (2007). Stres, mobbing $i$ wypalenie zawodowe [Stress, mobbing and burnout]. Gdańsk. [in Polish].

7. Mastalski, J. (2005). Szkolne interakcje zaburzajace skuteczne wychowanie [School interactions disrupting effective upbringing]. Kraków. [in Polish].

8. Maslach, C. (2000). Wypalenie - w perspektywie wielowymiarowej [Burnout - in a multi-dimensional perspective]. Sęk H. (red.), Wypalenie zawodowe. Przyczyny, mechanizmy, zapobieganie, Warszawa. [in Polish].

9. Pasikowski, T. (2000). Polska adaptacja kwestionariusza Maslach Burnout Inwentory, [Polish adaptation of the Maslach Burnout Inventory questionnaire]. Sęk H. (red.), Wypalenie zawodowe. Przyczyny, mechanizmy, zapobieganie, Warszawa. [in Polish].

10. Pines, A. (2010). Wypalenie - w perspektywie egzystencjalnej [Burning - in the existential perspective]. Sęk H. (red.), Wypalenie zawodowe. Przyczyny $i$ zapobieganie, Warszawa. [in Polish].

11. Przybyła, H. (1998). Psychologiczne koszty zespołu wypalenia zawodowego wśród nauczycieli a kierunki pomocy psychologicznej [Psychological costs of the burnout syndrome among teachers and directions of psychological help]. Rongińska T., Gaida W., Schaarschmidt U. (red.), Zdrowie psychiczne w zawodzie nauczycielskim, Zielona Góra - Potsdam. [in Polish].

12. Pyżalski, J. (2008). Obciażenia psychospołeczne w miejscu pracy pedagoga zwiazane z niewłaściwymi zachowaniami uczniów [Psychosocial workload at the pedagogue's workplace related to inappropriate student behavior]. „Medycyna Pracy”, 4. [in Polish].

13. Schwartz, M. \& Will, G. (1953). Low morale and mutual withdrawal on a mental hospital ward, „Psychiatry” 16/1953. [in English].

14. Schaufeli, W. \& Enzamann, D. (1998). The burnout compagnion to study and practice: A Critical Analysis, Taylor \& Francis, London. [in English].

15. Sekułowicz, M. (2005). Nauczyciele szkolnictwa specjalnego wobec zagrożenia wypaleniem zawodowym [Teachers of special education in the face of the threat of burnout]. Analiza przypadków, Wrocław. [in Polish].

16. Senejko, A. (2003). Podmiotowe czynniki wypalenia zawodowego [The subjective factors of burnout]. Witkowski S. A. (red.), Psychologiczne wyznaczniki sukcesu w zarzadzaniu, Wroctaw. [in Polish].

17. Sęk, H.(1996). Szkoła a wypalenie zawodowe [School and burnout], Poznań. [in Polish].

18. Sęk, H. (2014). Wypalenie zawodowe u nauczycieli [Professional burnout in teachers]. Brzeziński J., Witkowski L. (red.), Edukacja wobec zmiany społecznej, Poznań Toruń. [in Polish].

19. Szonert Rzepecka D. (2013). Wypalenie zawodowe [Occupational burnout]. Skłodowski H. (red.), Człowiek w kryzysie - psychospołeczne aspekty kryzysu, Łódź. [in Polish].

20. Śliwerski, B. (1993). Wypalenie zawodowe nauczycieli [Professional teachers' burnout]. Kropiwnicki J. (red.), Szkoła a wypalenie zawodowe, Jelenia Góra. [in Polish].

21. Travers, Ch. J. \& Cooper, C. L., Mental health, job satisfaction and occupational stress among UK teachers, Work Stress. [in English].

22. Tucholska, S. (2009). Wypalenie zawodowe u nauczycieli [Professional burnout in teachers]. Psychologiczna analiza zjawiska $i$ jego osobowościowych uwarunkowań, Lublin. [in Polish].

23. Wachowiak, J. (2011). Dysfunkcyjne zachowania pracowników [Dysfunctional employee behavior], Warszawa. [in Polish].

24. Wojciechowska, J. (1990). Syndrom wypalenia zawodowego [Burnout syndrome]. „Nowiny Psychologiczne", 5-6. [in Polish].

25. Woźniak-Krakowian, A. (2013). Syndrom wypalenia zawodowego nauczycieli [Burnout syndrome of teachers]. „Pedagogika”, 22. [in Polish].

26. Zając, D. (2011). Etyka zawodowa nauczycieli [Teachers' professional ethics]. Wybrane zagadnienia, Bydgoszcz. [in Polish].

Стаття надійшла до редакції 07.11.2018 